\title{
Imagined Insecurities in Imagined Communities: Manufacturing the Ethnoreligious 'Others' as Security Threats
}

\author{
By Michael I. Magcamit*
}

\begin{abstract}
How does a once familiar and benign ethnoreligious community become a stranger and a threat? This paper examines the underlying cyclical process that drives different ethnoreligious factions within a territorially bounded polity to frame each other as threats to their relative security and power position. By synthesizing interdisciplinary theories on security, religion, and nationalism, I develop a framework that explains how collective imagined insecurities are manufactured as tangible security threats. In particular, it identifies and describes the phases and the dynamics through which threatening conceptions and narratives about the ethnoreligious 'others' are developed, socialized, and legitimized. Applying this framework to analyze the lingering tensions between Muslim and Christian communities in Indonesia, I argue that this chauvinistic, zero-sum practice is underpinned by a three-phase cycle that is being precipitated by the emotive effects of ethnoreligious nationalism; hostile predispositions to securitize other ethnoreligious categories; and perceived indivisibility of sacred ethnoreligious homelands.
\end{abstract}

Keywords: ethnoreligious conflicts, security, religion, nationalism, threats, Indonesia

*Michael I. Magcamit, $\mathrm{PhD}$

Marie Skłodowska-Curie Fellow

School of Politics and International Relations

Queen Mary University of London

Address: Room 2.24 Arts One Building

Mile End Rd, Bethnal Green, London E1 4NS

Emails:m.magcamit@qmul.ac.uk / mim49@uclive.ac.nz

Tel No.: +44 07903-389216

Website: www.magcamit.com 


\section{Imagined Insecurities in Imagined Communities: Manufacturing the Ethnoreligious 'Others' as Security Threats}

\section{Introduction}

'Muslim power vanquishes the Nazarenes.' 'Christians conquer Muslim pigs.' These were examples of the graffiti that had been scrawled on the walls of ruined department stores in the capital city of Ambon in Maluku, following the violent conflicts between the Muslim and Christian communities in this eastern corner of Indonesia. Nobody expected that a trivial argument between a Christian bus driver and a Muslim passenger that happened on 19 January 1999 would end the Ambonese people's practice of building mosques and churches together as a means of facilitating peaceful relations between different ethnic and religious groups. In an instant, the once respected concept of pela-gandong (cultural friendship and brotherhood) which for generations had united the Muslims and Christians throughout the Maluku got buried underneath the rubble. Suddenly, everything came to be seen as a matter of a person's ethnicity and religion. According to one account, the riots and clashes that ignited in the city on that day spread across the island at such a rapid and alarming pace and were characterized by 'frenzied slaughter, savage mutilations, forced conversions, and the wanton destruction of property' (Schultze 2002, 57). Islamist militant groups and other independent radical Muslims from different parts of Indonesia flocked to the region to wage jihad on Indonesian Christians. The bloody war eventually claimed an estimated 10, 000 lives and displaced half a million Christian and Muslim inhabitants.

Meanwhile, some 550 kilometers from the provincial capital, a small clash erupted between the long-term migrant Makians and the native Kaos in a far-off village in Malifut on Halmahera island on the night of 18 August 1999. After destroying the Kao village of Sosol, thousands of Makians proceeded to attack the neighboring Wangeotak village where three Kao men had been killed (Wilson 2008). This marked the start of a series of fatal collisions that brought gruesome consequences to the whole region of North Maluku. Within just a couple of months, the predominantly Christian Kaos retaliated by expelling the Makian Muslims out of Malifut and 
destroying their villages. The circulation of a forged letter entitled, 'Bloody Sosol' (allegedly sent to the Protestant Church in North Maluku by a Protestant synod in Maluku) was used as a proof that the Kaos were planning to Christianize the entire province. Many observers argued that the letter provoked the Muslims in the islands of Ternate and Tidore to attack Christians who had been co-existing with them for years. Some of the most severe incidents took place in the subdistricts of Tobelo and Galela were sights of disfigured corpses, mass graves, and stories about consuming dead enemies' body parts became common. Although the eruption of violent hostility in Ambon initially had minimal effect on ethnoreligious relations in the region, the inauguration of an independent North Maluku province coincided with these brutal events that ultimately shattered half a century of peace and stability. By the time the battles ended in July 2000, between 3,000 to 3,500 were killed by the warring tribes; around 250, 000 were forced to flee; and tens of thousands of housing and infrastructure were ruined (Wilson 2008).

How does an ethnoreligious community that has once been seen as familiar and benign become a stranger and a threat? In this paper, I investigate the often neglected nonrational, nonmaterial processes that compel different ethnoreligious groups within a territorially bounded polity to frame each other as threats to their relative security and power position. To do this, I draw on the interdisciplinary theories on security, religion, and nationalism to develop and test a framework will help explain how imagined insecurities are manufactured as tangible security threats. Specifically, the framework identifies and describes the phases, and the dynamics in each of these phases, through which threatening conceptions and narratives about the ethnoreligious 'others' are developed, socialized, and legitimized. It consists of three principal components: cultivating ethnoreligious nationalism, securitizing the other ethnoreligious categories, and sacralizing indivisible ethnoreligious identities and homelands. The framework being proposed here, along with its principal components, is anchored on complementary theoretical assumptions about how the concepts of emotion, predisposition, and territorial indivisibility influence violent ethnic conflicts. Of particular importance here are Roger Petersen's (2002) emotion-based approach on ethnic conflict, Stuart Kaufman's (2006; 2019) symbolic politics and predispositions, and Monica Toft's (2003) indivisible geographies of ethnic violence.

Petersen's (2002) study on emotions and ethnic conflicts has provided crucial insights into 
individual motivation for beating, humiliating, or discriminating against another human being. He defines emotion as 'a mechanism that triggers action to satisfy a pressing concern' and operates to address situational challenges by (1) raising the saliency of one desire/concern over others and (2) heightening the required cognitive and physical capabilities to respond to situational challenges (Petersen 2002,17-18). This emotion-based theory of ethnic conflict argues that emotion is a mechanism that explains shifts in motivation by mediating between cognition and desire, driving individuals to reach a recognizable goal (Petersen, 2002: 19-20). Here, cognition is viewed prior to the causal sequence for fear, hatred, and resentment: 'Beliefs about threat lead to fears; beliefs about status inconsistency lead to resentments; beliefs about history and vengeance lead to hatreds' (Petersen 2002, 21). As Andrew Ortony, Gerald Clore, and Allan Collins $(1998,2)$ have posited, 'if an individual conceptualizes a situation in a certain kind of way, then the potential for a particular type of emotion exists.' In other words, the situation gives rise to a conceptualization which in turn gives rise to the emotion. Together, these theoretical propositions about how emotions influence violent conflicts help explain the dynamics underpinning the first phase of my three-pronged framework: cultivating the emotive effects of ethnoreligious nationalism.

Meanwhile, building on Petersen's work, Kaufman's $(2006,2019)$ symbolic politics theory uses evidences from neuroscience studies to demonstrate how emotions, rather than rational calculations, are motivating people to act. In developing his theory of ethnic conflict, Kaufman $(2019,3)$ focuses on what he refers to as 'symbolic predispositions' defined as 'stable affective responses to particular symbols'. Symbols are considered powerful precisely because they 'simultaneously refer to an interest and to an emotionally laden myth...often framing a conflict of interest as a struggle against hostile, evil, or subhuman forces' (Kaufman 2006, 52). This is based on the notion that since attitudes which have originally formed emotionally are more sensitive to emotional than to intellectual appeals (Edwards 1990; Edwards and von Hippel 1995), ordinary people tend to decide and choose emotionally among opposing values and leaders by reacting to the most evocative symbol depicted to them (Kaufman 2001; Ross 2001). Consequently, cunning politicians are routinely evoking emotions - such as fear, resentment, and hatred - by reinterpreting conflicts of interest as struggles for collective security, status, and 
future to motivate people to take actions (Kaufman 2006). This helps explain why politicians' rhetoric usually favor symbolic appeals to group identity, ideology, morals, and even prejudice over rational arguments (Kaufman 2019). As Drew Westen (2007) contends, since political opinions are being shaped more by predispositions than facts, leaders are forced to make emotional appeals to those predispositions. Together, these theoretical propositions about the role of symbolic politics in violent conflicts help illuminate the dynamics underpinning the second phase of my framework: securitizing the other ethnoreligious groups using hostile symbolic predispositions.

Finally, Monica Toft's (2003) thesis on the geography of ethnic violence shows what the focal referents of these emotions and predispositions are: indivisible territories. The theory of indivisible territory treats territory as a material resource (an object) that can be divided and exchange, and at the same time, a nonmaterial value (a subject) that cannot be divided or exchanged (2003). It argues that 'controlling territory is of great importance to ethnic groups and to states because both actors believe their survival depends on it' (Toft 2003, 19). Although their views about the relationship between territorial control and survival differ, as far as the ethnic groups are concerned, their territory is a defining feature of their identity - inseparable from their past and crucial to their continued existence as a distinct tribe (Toft 2003). Here, territories are considered as homelands that seem fixed in time and in the imagination, taking on meanings beyond their material and objective descriptions. Since these homelands contain the 'fundamentals of culture and identity', their cultural boundaries and boundedness must always be preserved (Morley and Robins 1994, 8). Another way to put this is that, because they are an indivisible attribute of collective identity and not objects to be exchanged, the 'others' are constantly seen as threats to the security and integrity of the in-group. Thus, notwithstanding the territory's objective economic worth, ethnic groups rationally view the right to control their respective homelands as a survival issue (Toft 2003). Together, these theoretical propositions about territorial indivisibility and violent conflicts help illuminate the dynamics underpinning the third phase of my framework: sacralizing indivisible ethnoreligious identities and homelands. The following sections explain in greater details the construction and composition of each of the three phases of the framework. 
Combining logically interdependent theories on security, religion, and nationalism from Political Anthropology, Political Sociology, and Political Psychology, I develop a framework that enables a more nuanced but still systematic approach to understanding the phases (and the dynamics within each phase) through which collective imagined insecurities are manufactured into tangible security threats, thereby transforming the once familiar and benign ethnoreligious community a stranger and an enemy. Drawing on the theoretical propositions regarding the respective roles of emotion, predisposition, and territorial indivisibility vis-à-vis violent ethnic conflicts, I identify and describe three interrelated phases through which the effects of these conceptual elements are manifested and concretized. These are: (1) cultivating the emotive effects of ethnoreligious nationalism; (2) securitizing the ethnoreligious others using hostile symbolic predispositions; and (3) sacralizing the indivisible ethnoreligious identity and homeland. In order to demonstrate how each phase of the framework contributes to the entire cyclical process of manufacturing the ethnoreligious others as security threats, I provide an empirical analysis of the lingering tensions between Muslim and Christian communities in Indonesia using processtracing. Drawing on these theoretical and empirical exercises and the evidences from my fieldwork in Indonesia, I advance the argument that such chauvinistic, zero-sum practice is performed via a three-phase process that is being precipitated by the emotive effects of ethnoreligious nationalism; predispositions to securitize other ethnoreligious categories; and perceived indivisibility of sacred ethnoreligious homelands.

Cultivating the emotive effects of ethnoreligious nationalism (Phase 1): Muslim versus Christian nationalisms in Indonesia

Ethnoreligious nationalism refers to the amalgamation of ethnic nationalism and religious culture which powerful elite actors use not only for masking certain material interests but also for ascribing identity (Baumann 1999; Hastings 1977; Juergensmeyer 1993; Kinnvall 2007). Whereas nationalism signifies a form with variable content, ethnicity and religion act as implements that specify the content of this form (Brubaker 2012; Friedland 2001; Smith 2000). Specifically, while nationalism articulates the necessity of binding the state, territory, and culture together without defining the exact method and content of this amalgamation, ethnoreligion offers a distinct 
method and content by generating 'models of authority' and 'imaginations of an ordering power' that regulate and control the various of aspects of life (Friedland 2002, 390). When different ethnic nationalisms are infused with different religions, different communities are compelled to create, propagate, and secure their conceptions and narratives of identity and homeland in their own ethnoreligious terms. To this extent, ethnoreligious nationalism generates the necessary and affective emotive lexicon which political and ethnoreligious elites exploit to: (1) facilitate and institutionalize the 'othering' between the 'legal' insiders and the 'illegal' outsiders by serving as a fundamental reservoir of identity; and (2) frame and legitimize calls for mobilization to either revise or preserve the existing structural conditions and power hierarchies affecting the group's relative security and power position (Brubaker 2012; Friedland 2001; Juergensmeyer 1996; Spohn 2003).

However, it is important to note that the elites do not have the absolute monopoly in deciding when and how to use the emotive effects (e.g. fear, hatred, and resentment) that emerge from the cultivation of ethnoreligious nationalism. The direction of influence goes both ways. While elite actors could certainly develop and manipulate emotions to secure their own ends particularly in times of structural changes, nevertheless, it could also be the case that elite actions are responses to mass emotions amidst structural shifts rather than shaping those emotions (Petersen 2002). This means that the elites are not the only ones that utilize emotions to achieve their economic and political motives. Ordinary people also pursue multiple plausible motivations at different times based on these emotions that function as 'a switch among a set of basic desires' (Petersen 2002, 37). To quote Ivelin Sardomov: 'Portraying millions of individuals in many societies as mindless robots who can easily be duped into assuming fictitious identities and sacrificing their own and others' lives for the purposes of a small group of skillful self-serving manipulators represents an extremely simplistic and condescending view' (in Petersen 2002, 36). The day-to-day exchanges and interactions among the majority of the people and the emotional content and weight of those lived experiences also shape elite behavior and guide their conduct.

Within a territorially bounded plural polity, for example, 'birthright' ethnicity, religion, and land are depicted as fixed and indivisible components of individual and collective being. The fear, hatred, and resentment that could arise from emotion-based narratives of ethnoreligious 
nationalism generate a shared view among competing groups that they are ultimately responsible for the protection and preservation of their own identity and homeland. In Petersen's $(2002,19)$ formulation, 'fear prepares the individual to satisfy safety concerns; hatred prepares the individual to act on historical grievance; resentment prepares the individual to address status/self-esteem discrepancies.' Crafting an emotional language that revitalizes and secures their respective identities and territories becomes fundamental to their salvation. To this end, ethnoreligious leitmotifs and imageries are constantly mined to build and entrench the foundations of the groups' imagined communities, enabling them to control their conceptions and narratives of the outsiders with respect to the insiders (Anderson 1983; Armstrong 1997; Brubaker 2012; Hastings 1977; Kinnvall 2007).

Ethnoreligious nationalism then becomes a matter of identifying and differentiating the 'legitimate' identity from the 'illegitimate', as well as the 'lawful' inhabitants of the homeland from the 'unlawful' ones. Although conventionally, nationalism has been viewed as a means to identify and describe the 'self' in relation to the others living outside of a territorially bounded polity, with a particularistic (as opposed to universalist) ethnoreligious nationalism, the others are also insiders residing within the boundaries of that same polity. It provides a medium through which the collective emotions of a particular ethnoreligious group are summoned to rally the ranks into actions against other identify forms and versions of the homeland that threaten to undermine and delegitimize their existence (Ashmore et al. 2008; Hughey 1998; Stavenhagen 1996). In this regard, ethnoreligious nationalism does not simply ascribe identity to the act of conceiving and sustaining the homeland but also establishes the 'chosen glories' and 'chosen traumas' that must be glorified, the stories and symbols that must be venerated, and the relationships and loyalties that must preserved (Volkan 1998). Manufacturing a homogenous ethnoreligious culture and composing a grand narrative of the homeland based on some imagined 'ideal' and 'legitimate' form of identity suppresses all other sources of histories, memories, and allegiances (Smith 2003; Zubrzycki 2017). Hence, constructing an identity and a forming homeland are not exclusively tied to modern a charter or a secular constitution but are embedded and expressed along deeply entrenched ethnic and religious divides. 
In Indonesia, ethnoreligious nationalism has always been integral to the conception of 'national' identity and homeland despite the perceived strength of secularism. Islam has and continues to be at the heart of nation-state building process given its status as the predominant religion in the archipelago. The absence of other unifying vehicles such as language, history, or a profound awareness of shared territory has made Islam a binding force that gave form and substance to Indonesia's nationalist struggles - with distinctive Javanese cultural persuasions during its nesting years (Aspinall et al. 2001; Hamayotsu 2002; Hoey 2003). Prior to the establishment of various Islamic resistance groups, expressions of bourgeoning anti-Dutch resistance in the earlier periods of their colonial rule had already adopted certain religious undertones. This was evident, for instance, during the Padri War (1803-1837) in West Sumatra between the reformist Muslim clerics who wanted to impose Shari'a in Minangkabau and abolish all 'un-Islamic' customary laws found in the Adat, and the traditional chiefs and nobility who were supportive of these indigenous rights and pre-Islamic practices (Liow 2016; van Klinken 2003).

Through intensifying transnational interactions linked to the Hajj, the emerging Islamic political thought and social activism in the Middle East and North Africa reached the shores of Indonesia and stimulated the growth of patriotic feelings and collective aspirations articulated in deep ethnoreligious terms (Laffa 2003; Roff 1967). This marked the beginning of Islam's instrumentalization as a signifier of a developing national identity, guiding the construction of narratives and discourses of opposition and character affirmation vis-à-vis the Dutch colonialists. The Muslim faith became a sacred symbol of an imagined national community; whereas the Muslim identity became a figure of militant resistance against the colonial regime's exploitation of the homeland. The birth of Islamic organizations including the Sarekat Islam, Muhammadiyah, and the Persi in the $20^{\text {th }}$ century had further advanced the fermenting Islamic nationalism in Indonesia as they undertook serious strides in molding the content and course of the nationalist revolution, and in training their members to become fervent Muslims and faithful citizens of the impending Indonesian nation-state (Federspiel 2009). Islam provided both the emotional reservoir which the local elite actors had mined to cultivate Muslim nationalism among their 
people, and the vernacular device which had been utilized to assert the formation of an independent Islamic nation-state.

Nevertheless, the universal applicability and effectiveness of these emotional and vernacular mechanisms were substantially undercut by Christianity's successful expansion in the eastern parts of the Indonesian archipelago. The transfer of Netherlands East Indies' administration from the Vereenigde Oostindische Compagnie (VOC) to the Dutch government coincided with the reformation of orthodox Christianity and the rise to power of the AntiRevolutionary Party headed Abraham Kuyper who became the prime minister from 1901 to 1905. As a reformed theologian himself, Kuyper authorized the Dutch, German, and North American missionaries to bolster their evangelization efforts, believing that the Christian indigenous folks were easier and more loyal subjects than the non-Christian ones (van Klinken 2003). While the gradual progression of Christianity had made the Muslims wary and suspicious of the Christians, nevertheless, they did not expect that it would pose serious risks to Islam's dominance and position within the Indonesian society at that time. ${ }^{1}$ But as the anti-colonial movement started to ignite and confront the rulers of the Dutch East Indies, the notion of ever-expanding Christian influence and entitlement exposed the underlying distrust, resentment, and hostility that were increasingly felt by the Muslim majority (Abuza 2006; Feillard and Madinier 2011). The lingering fear of Kristenisasi (Christianization) on the part of conservative Muslims and the widespread view of the Christians as Dutch collaborators had further amplified and entrenched the underlying ethnoreligious divide between the two groups, and would eventually provoke fierce discussions about how to conceive and construct Indonesia's post-colonial identity and homeland.

Indeed, as the chief architects of the newly independent albeit fledgling Indonesian government soon found out, the fragmentation of domestic politics along sharp ethnoreligious cleavages was extremely problematic for the management of Muslim and Christian relations. When Indonesia gained independence on August 17, 1945, the leaders and the elites of the new state were split between two polarized factions. One group supported the establishment of a

Author's interview with a key informant in Jakarta, Indonesia on August 11, 2017. 
nationalistic, secular, and inclusive Indonesian state, whereas the other promoted the creation of a more traditional and conservative state based on Islamic values and principles (Arifianto 2009; Husein 2004; van Klinken 2007). The brewing antipathy between the two sides finally exploded when the latter demanded that the preamble of the Indonesian Constitution known as Piagam Jakarta (or Jakarta Charter) should read as follows: 'a Republic founded on the principles of the Belief in One God, with the obligation for adherents of Islam to practice Islamic law' (Boland 1982, 26). Moreover, the conservatives also insisted on inserting additional clauses that would make Islam as Indonesia's only official religion and would require the president of the republic to be 'a native-born Indonesian who is a Muslim' (Elson 2009; Hosen 2005).

Christian politicians had been hostile to these proposals and accused their Muslim counterparts of attempting to form a post-independent Islamic state that would suppress the rights and status of the non-Muslims. ${ }^{2}$ They warned about the possible secessions of regions in Eastern Indonesia with substantial Christian populations (such as North Sumatra, Kalimantan, North and West Sulawesi and Moluccas) if these sections were included in the new constitution (Liow 2016). Interestingly, the Christian fight against the institutionalization of a highly sectarian order was backed by some secular Muslim leaders who were more inclined toward a building a republic with a more flexible religious persona and, therefore, also rejected the forceful espousal and implementation of Shari'a laws (Arifianto 2009). Fueled by their longstanding grievance toward Javanese dominance and anxiety over the looming Islamisasi (Islamization) of the entire archipelago, the Christians had lobbied clandestinely against the advocates of the Jakarta Charter (Arifianto 2009; Liow 2016). After intense deliberations, the Preparatory Committee for Indonesian Independence (PPKI) decided to adopt the Jakarta Charter without the Shari'a clause in order to promote a more 'holistic' form of theism which should serve as the fundamental cornerstone of modern Indonesia.

This decision was consistent with the Pancasilla principles articulated earlier by President Sukarno in his speech to the Committee for the Preparatory Work for Indonesian Independence (BPUPKI) on June 1, 1945. According to Sukarno, the constitution of post-independence

\footnotetext{
Author's interview with a key informant in Jakarta, Indonesia on August 11, 2017.
} 
Indonesia must be anchored on five universal principles and shared values, namely: (1) a belief in the one and only God; (2) a just and civilized humanity; (3) the unity of Indonesia; (4) consultative democracy; and (5) social justice for the whole of the people of Indonesia (Morfit 1981; Mortimer 2006; Schwarz 2018). The employment of Pancasilla was a strategic attempt to recognize the desire of traditionally conservative Muslims to erect an unambiguously Islamic nation-state, while mitigating the risks of unravelling and disintegrating Indonesia's society and territory. For Sukarno and the PPKI, the omission of the Shari'a article was a crucial step to ensuring the growth and security of the infant nation-state's conceptual cohesion and material integrity.

Notwithstanding these intentions, the ultimate rejection of the much-debated clause engendered a deep sense of betrayal on the part of Islamist nationalist groups who argued that given Indonesia's status as the world's largest country with the biggest Muslim population, the nation-state must be essentially Islamic both in form and in character. In addition, considering the significant role that Islam had played in nationalist movements that gave Indonesia and her people their freedom, they believed that Islam deserved to have a special and privileged position in the constitution. ${ }^{3}$ The fact that that their mission was thwarted by the coalition between a small but disproportionately influential cluster of Christian leaders and secular nationalist elites further agitated the traditionalist Muslims who had always been suspicious of Christianity's role in Dutch colonization. ${ }^{4}$ Meanwhile, the more radical and extreme camps scattered in the provinces of West and Central Java, South Sulawesi, South Kalimantan, and Aceh, decried the direction and legitimacy of the new government and embanked on armed rebellion to pursue their aspiration to establish an Islamic Republic (Abuza 2006; Basweda 2004; Feillard 2011). These mounting tensions over diverging post-colonial conceptions and narratives of the Indonesian identity and homeland set the playing field for continuing struggles over the core principle and thrust of nation and state building.

\footnotetext{
${ }^{3}$ Author's interview with a key informant in Yogyakarta, Indonesia on August 15, 2017.
}

* Author's interview with a key informant in Yogyakarta, Indonesia on August 16, 2017. 
Securitizing the rival ethnoreligious groups using hostile symbolic predispositions (Phase 2): Muslim versus Christian 'threats' in Indonesia

The emotive effects generated by ethnoreligious nationalism motivate an ethnoreligious group, particularly its political and religious elites, to securitize rival factions as threats to their security and power position based on some underlying symbolic predispositions. Specifically, the securitization process provides crucial insights on how the negative emotions of ethnoreligious nationalism and the hostile predispositions which they help produce transform the 'othered' ethnoreligious categories into 'existential threats'. Instead of thinking of security as being tangible or concrete, it is best viewed as a process through actors are able to frame specific issues as security threats (Wæver 1995). As Barry Buzan, Ole Wæver, and Jaap de Wilde $(1998,24)$ have asserted, security is self-referential because 'an issue becomes a security issue, not necessarily because a real existential threat exists but because the issue is presented as a threat.' Actors that 'are placed in positions of power by virtue of being generally accepted voices of security' and, therefore, widely perceived as 'holders of the collective identity' are referred to as securitizing actors (Buzan et al. 1998, 23). The Copenhagen School's understanding of security as a structured field suggests that while everybody can theoretically become a securitizing actor, political and religious elites are best placed to craft and legitimize security discourses given their social capital and deep knowledge of the context (Buzan et al. 1998, 31). By acting as powerful norm and discourse entrepreneurs, they are able to facilitate considerable degree of attitudinal conformity among their followers and supporters (Bosco 2014; Hassner 2003; Karyotis and Patrikios 2010).

Elevating certain issues such as the presence of other ethnoreligious communities as security issues, enables these securitizing actors to justify their calls for adopting 'extraordinary measures' beyond the realms of normal politics and its established rules. To this extent, a securitization act does not only describe the realities of the current security context but plays actively constructs and reconstructs these realities (Balzacq 2010; Floyd 2011; Stritzel 2007). In doing so, it facilitates new approaches to collective self-understanding, which in turn, shape group perceptions about what the 'real' existential threats are and who must be legally protected from these threats. In effect, it is by articulating the security threats and identifying the 'legitimate' referent objects of these threats that they are brought into being. As Wæver $(1995,55)$ has 
succinctly put it, 'the word security is the act', which means that security is essentially a speech act. Through this securitizing speech act, influential elite actors are able to present and, if necessary, dramatize a specific security issue as an absolute priority of the group in question.

When formulating these speech acts, securitizing actors often draw from the hostile symbolic predispositions of their audience (i.e. the members of the referent group that must be secured) which they acquire and develop from their community's equally hostile ethnoreligious substructures (i.e. doctrines, myths, dogmas, and norms). Similar to how the emotive effects of ethnoreligious nationalism are cultivated and utilized, the direction of influence when securitizing rival ethnoreligious groups also goes both ways: dominant elite actors are simultaneously utilizing and are being influenced by these substructures and predispositions either substantively (i.e. genuinely motivated) and/or tactically (i.e. exploited for strategic purposes). Examples of these are prejudice and ethnocentrism which are both considered hostile as they prompt individuals 'to feel negative emotions such as hostility or distrust toward others' (Kaufmnan 2019,4). Based on Kaufman's (2009) formulation, predispositions generally have a two-way relationship with feelings of threat. When confronting an ambiguous behavior by another ethnoreligious group, the members of the in-group would likely to feel threatened if they possess negative stereotypes about the former (Alexander et al. 1999; Riek et al. 2006). Similarly, despite initially having positive predispositions toward other factions, when the members of the in-group are facing an obvious threat, the threat functions as a 'psychological shock' that can still induce hostile predispositions (Kaufman 2019, 4). The zero-sum nature of these predispositions ultimately generates a condition in which the perceived security and power of the referent group ultimately depends on the relative insecurity and weakness of all other target groups.

To begin with, how the others are conceived is integral to how the in-group views and understands itself. Indeed, the primary impetus behind the securitization of the other groups as threats underlines the view among members of the in-group that they are the primary referent objects of security. As the anxiety and paranoia being felt by the referent group amplify, so do the members' fears, hatred, and resentment toward the target groups. The result is the framing of other ethnoreligious categories as sources of identity crisis and homeland instability. Yet, the more that the other groups are vilified and excluded, the more that they are compelled to 
reexamine and revisit their respective ethnies and religions on which they could anchor their own identity and homeland. These dynamics engender an internal security dilemma in which any attempts to improve one group's situation and status diminish that of that of the other. Be that as it may, the structural imbalances that emanate from this arrangement are deemed crucial to the continued survival of ethnoreligious factions, particularly on the part of more dominant groups which have the capacity to secure greater power and higher position.

Catarina Kinvall's (2004) conception of the 'abject-other' helps explain how the securitization of rival groups based on hostile symbolic predispositions discourse shapes and reshapes individual and group understanding and interpretation of the reality. In portraying the once familiar and benign 'others' as security threats, the 'abject' becomes a key part of collective identity formation. Manufacturing the others into enemies necessitates their systematic debasement and dehumanization resulting in the perception of the others as being 'dirty, despicable and worthless nonhuman' (Kinnvall 2004, 753). This allows the referent group to feel more secure and less anxious about its own security and standing because it gives its members the assurance that they are inherently different and superior than the others. When this version of the reality reaches an authoritative status, hostile conceptions and narratives of the others become socially powerful and end up being accepted as the only correct and worthwhile perspectives.

Projecting anything that it is considered threatening or unpleasant about the self onto the other sacralizes one's identity and homeland while desacralizing all other strangers and their respective homelands. With the reduction of the strangers into inhumanity, extraordinary measures in the forms of 'chauvinist mobilizations' (e.g. Herrmann 2017; Kaufman 2019) and 'extractive institutions' (e.g. Acemoglu and Robinson 2012; Bull 1977) believed to prevent the 'dirty' and 'evil' other from contaminating the 'pure' and 'holy' self are legitimized and defended. Over time, these perceived differences between ethnoreligious communities come to be seen as natural and intrinsic features that distinguish and separate the legitimate insiders from the illegitimate outsiders. To quote Robert Robins and Jerrold Post (1997, 94-95), 'the movement must strengthen its walls against the enemy without and search for enemies within... true belief does not permit question and doubt.' 
In Indonesia, during the course of Dutch colonialism, the eastern province of Maluku (comprised of central and southern Maluku islands) developed along a strikingly different course from the main islands of Java and Sumatra. Christianity (in particular, Calvinism) was resolutely promoted by the colonial rulers and proliferated at a much faster pace than in other East Indies provinces (Aritonang et al. 2008). Rather than resisting, the native Maluku people provided the Dutch colonial army with a large number of well-trained soldiers and fought alongside their European colonizers against the Japanese military forces during the Second World War (Schulze 2001; van Klinken 2003). After Japan's capitulation and defeat in 1945, nationalist leaders from Java unilaterally declared Indonesian independence without the consent and approval of all regions and populations across the archipelago. The indigenous people of South Maluku, supported and aided by the Dutch government and military, were among the earliest organized groups that opposed this move. The rebels demanded for the recognition of an early post-colonial treaty between the Netherlands and the Republic of Indonesia which prescribed the establishment of a federal form of statehood (Goss 2000). When the agreement failed, the demobilized soldiers of the former Royal Dutch East Indies Army and other separatists who remained loyal to the Dutch crown revolted and proclaimed the formation of the Republik Maluku Selatan (Republic of South Maluku or RMS) on April 25, 1950 (Turner 2003; Wilson 2005).

The Indonesian army swiftly extinguished the rebellion and absorbed their territory into the Republic of Indonesia, allowing Sukarno to pursue his vision of a unitary state. Since then, the RMS has become a pejorative term used by Muslim nationalists to refer to Christian separatism, colonialism, betrayal. Nevertheless, the establishment and facilitation of the New Order under the Suharto regime from 1966 to 1998 gave the Christian and moderate Muslim elites (the abangan) preferential entry pass to government and bureaucratic positions, while limiting the access of conservative Islamic groups and their members (the santri) to the arcades of power. ${ }^{5}$ As a preventive measure against the growing hostility and opposition coming from the santri, Suharto cultivated good relations with the Christian groups, believing that they could serve as buffers should a full-scale political resistance against the New Order arise. This resulted in

\footnotetext{
Author's interview with a key informant in Jakarta, Indonesia on August 13, 2017.
} 
accusations by conservative Muslims that the Christian leaders were exploiting the ongoing turmoil between Islam and the regime to further promote Kristenisasi and entrench their influence at the expense of conservative Muslims and their religion (Arifianto 2009; Liddle 1996; van Bruinessen 2002).

The irony of having less political power and economic resources despite being the majority ethnoreligious group amplified the enmity and resentment being harbored by the santri toward Christian populations. ${ }^{6}$ Moreover, the heightened sense of discrimination felt within fundamentalist Islamic communities fueled the emergence of 'Christian threat' narratives which tackled how the state's alleged promotion of Christianity and connivance with its leaders were detrimental to Islamic values and Muslim interests. The personalities behind the spread of antiChristian discourses criticized the use of material inducements such as hospitals, schools, and money for convincing Muslims to convert into Christianity; while others compared those foreignfunded Christian missionary efforts across the Indonesian archipelago as yet another form of neocolonialism (Liow 2016). Such rhetoric and the images that they conjured propagated the idea that Suharto's New Order was a deliberate plan to purge the Muslim political and religious elites along with the Islamic parties and organizations (Bertrand 2004; van Bruinessen 2002). This combined atmosphere of Muslim insecurity and Christian hostility that emanated from these conditions set the stage for the eruption of violent ethnoreligious conflicts between the two factions.

With the resurgence of Islam and the revival of the faith of Indonesian Muslims, however, Suharto dramatically reoriented his New Order approach. After suppressing and strictly regulating the political activities of Islamist and conservative Muslims between 1960s and mid1980s, he started embracing and actively co-opting them into his sphere of influence from late1980s until his regime's demise in 1998 (Liddle 1996; Nenchik 2016). The government gradually started rolling out a series of policies accommodating their demands to appease their feelings, specifically with regard to their deep-seated concerns about the threats of Kristenisasi in Indonesia. ${ }^{7}$ Among these was a joint decree between the Ministry of Religious Affairs (MRA) and

\footnotetext{
- Author's interview with a key informant in Jakarta, Indonesia on August 13, 2017.

Author's interview with a key informant in Yogyakarta, Indonesia on August 17, 2017.
} 
the Ministry of Home Affairs (MHA) requiring religious organizations that wanted to build new places of worship written permissions from the heads of the local government (the bupati) and the MRA. Permits would be administered only after a successful consultation with the bupati and local religious leaders concerning the impacts of the proposals on the existing relations between ethnoreligious communities (Crouch 2011, 2007). These stipulations have disproportionately benefited Islam given its dominance in most parts of Indonesia, enabling Muslim leaders to arbitrarily reject the proposals presented by non-Muslim minorities. Since its implementation, Christian organizations not only started to face enormous challenges in securing state permits to build new churches, but incidents of vandalism and burning of their existing ones significantly increased (Crouch 2007). Consequently, many had been forced to convert private houses into churches but since the decree also made this activity illegal, conservative Muslims found yet another reason for disrupting and destroying them.

The MRA also issued complementary decrees that limited the activities of foreign missionaries including the evangelization of individuals and groups who were members of officially recognized religions. While in theory, these policies covered all official religions in Indonesia including the conservative Muslims, the Christians felt that they were being targeted and argued that their enactment violated religious freedom (Bowen 2003; Mujani and Liddle 2009). More importantly, Suharto had also begun replacing Christian government ministers, military officers, and other chief bureaucrats with well-known devout Muslims. This would explain the lack of any significant Christian representation in the Sixth Development Cabinet (1993-1998) as the highest government posts including finance, labor, education, and the armed forces were given to the santri Muslims. The ejection of Christian elites from the corridors of power drastically undermined the religious rights and privileges which had been previously afforded to them, as well as their capacity to provide patronage for powerful government officials. The turning of tables triggered immense anxiety and paranoia among the Christian populations, fearing that the conservative Muslims who were now running the government would employ Islamisasi to persecute them. ${ }^{8}$

s Author's interview with a key informant in Jakarta, Indonesia on August 14, 2017. 
Like a self-fulfilling prophecy, immediately after the collapse the New Order, Indonesia suffered some of the most brutal and violent ethnoreligious conflicts in its history. The fall of Suharto finally ignited the ethnic tensions and religious frictions that had been fermenting for decades, erupting to vicious bloodsheds between dueling tribes that were trying to completely destroy and slaughter each other's communities and villages. Underlying historical legacies significantly contributed to the horrific scale of violence that ripped Maluku's Muslim and Christian communities apart and transformed the province into a notorious site of extreme ethnoreligious conflict and discord overnight. ${ }^{9}$ What made these series of violence and their outcomes particularly remarkable was the fact they were often precipitated by unrelated incidents that immediately been transformed into vigilante movements mobilized along ethnoreligious cleavages.

The surrounding climate turned for the worse when external entities (such as the Laskar Jihad, Laskar Mujahidin, Jemaah Islamiyah, and KOMPAK) decided to intervene in the ongoing clashes in Maluku to help the Muslims in their fight against the Christians, thus adding more complications to the already tense situation (Schulze 2002; Sidel 2006). For one, their arrival further amplified the ethnoreligious dispositions of the opposing enclaves, resulting in more radicalized Islamic narratives of jihad espoused by the Laskar Jihad and the Laskar Mujahidin and Christian discourses of crusades promoted by the Maluku Sovereignty Front (Goss 2000; Wilson 2008;). The rampant use of sacred imageries and symbols by combatants from both quarters such as the alleged sightings of angels on battle horses on the part of Muslim militants or the reported apparitions of Jesus Christ and the Virgin Mary on the Christians' side - also created a sense of an impending apocalypse that provoked even greater religious fanaticism among the populations of Maluku (Bubandt 2001; Spyer 2002; van Liere 2011). The intensified clashes resulting from these developments legitimized the victim status of the 'pure' insiders but also justified the violent attacks toward the 'impure' outsiders, transforming the once peacefully coexisting villages into exclusive Muslim and Christian territories that sharply fractured the region.

Sacralizing the indivisible ethnoreligious identity and homeland (Phase 3): Muslim versus

'Author's interview with a key informant in Jakarta, Indonesia on August 14, 2017. 


\section{Christian 'Indonesia'}

With the successful cultivation of the emotive effects of ethnoreligious nationalism (Phase 1) and effective securitization of the 'threat' of rival ethnoreligious groups using hostile symbolic predispositions (Phase 2), the political and religious elites further solidify the status and legitimacy of their groups by sacralizing their respective ethnoreligious identities and the homelands that they claim to possess. They do so by attempting to embed their own ethnoreligious substructures within the underlying security superstructures (i.e. rhetoric, policies, strategies, and institutions) of the overarching state. This means that the security and survival of a particular group depends on its capacity to continuously enhance and maintain its structural power position within a territorially bounded heterogenous polity relative to other groups. Being at a peripheral position suggests that the group's ethnoreligious substructures are too weak to influence the creation of security superstructures that can provide greater privileges and space for its members.

This scenario is particularly relevant in states that have relatively more recent and fragile territorial boundaries due to their experience with colonialism particularly in Southeast Asia. In many of these polities, religious elites are often seen as the primary custodians of 'national' identity and homeland. Views about right and wrong, good and evil are also guided by different ethnoreligious substructures that are continuously being observed in virtually all parts of the region. Because belief systems are deeply ingrained into individual thought process and societal consciousness, any threat to their infallibility is regularly ignored or suppressed (Kinnvall 2004; Robins and Post 1997; Wentz 1987). In other words, when confronted with issues that question a person's or a group's 'constitution of being as such', those who are at risked cannot afford to be too rational with their response (Bagge Laustsen and Waever 2000, 719).

This makes religious elites seem more credible and trustworthy than their political counterparts and in turn, give their rhetoric more weight than secular political discourses (Fox and Sandler 2004; Thomas, 2005; Hatzopoulos and Petito 2003; Johnston and Sampson 1995). The social power that they possess transforms them into 'divine authorities', allowing them to influence the state actors responsible for crafting the state's security superstructures, particularly those who are also members of their group. This indicates that the political elites are not simply 
politicizing ethnoreligious substructures in pursuit of their own interests but their conduct of politics and the political channels through which they operate are also being influenced and constrained by these nonmaterial, nonrational elements. While they certainly have some tactical interests, nonetheless, it is highly plausible that they are also being driven by substantive motivations. Put differently, it cannot just be assumed that the political elites do not believe in their group's ethnoreligious cause or that the ordinary people are passive victims of elite manipulation and predation. To do so is to misread and miscalculate the power of ethnoreligious nationalism. Even when they do manipulate and exploit these ethnoreligious substructures, their constructions, as Toft $(2003,9)$ argues, 'become embedded in history, perception, and interpretation', which means that political elites also become 'beholden to this constructed reality if they want to stay in power.'

In states where 'national identity' is conflated with the ethnicity and the religion of the majority, the situation becomes more pronounced. On the one hand, the majority's ethnoreligious myths and doctrines heavily inform the security rhetoric and policies (which define who the legitimate referents of national security are and what measures must be taken to the threats to these referents) that are being crafted by state elites. On the other, the security strategies and institutions that state officials end up implementing further legitimize and entrench the norms and dogmas associated with the majority ethnoreligious cluster. Here, rather than constructing their own ethnoreligious group's interests, state elites represent them. This means that their capacity to make or negotiate concessions is significantly reducing, hence becoming 'captive to the policies and discourses that helped them gain power' (Toft 2003, 140). Nevertheless, this act of implanting the hegemonic ethnoreligious nationalism when configuring national security sacralizes the resulting security superstructures, which in turn, fortify the foundations of the majority's ethnoreligious identity and homeland. Overtime, the ethnoreligious substructures acquired by the majority and the security superstructures made from these become axiomatic components of nation-state building, making the existing order seem right and natural, one that must be preserved despite the systematic marginalization of the 'polluted' others (Bauman 2001; Robins and Post 1997). Opposition against this majority-centric arrangement is often interpreted as rebellion against the nation's 'god' and its most favored people and, therefore, is treated as a 
national security threat.

Since the identity and the homeland are deemed indivisible components of survival and, therefore, cannot be shared with the outsiders, ethnoreligious groups believe in some form of a 'just war'. War and bloodshed are seen as regrettable albeit necessary instruments for protecting the pureness of their identity and the sacredness of their homeland (Elshtain 1992; Hassner 2007). Determining the legitimate 'daughters/sons of the soil' then becomes a paramount issue that leads to the symbolic rejection and social expulsion of the others into the 'zone of killing' (Stevens 1997). These myths of purity, chosenness, and sanctity - rooted in the cultivation ethnoreligious nationalism and the securitization of rival factions - rationalize both the ideology of the ensuing just war and the method for waging this war. The goal of which is to perfectly align a group's ethnoreligious identity and homeland together where the members could 'sing the same hymns, listen to the same gospel, share the same emotions, linked not only to each other but to the dead beneath their feet' (Ignatieff 1993, 95).

In Indonesia, former president B. J. Habibie's efforts to transform the government system into a democracy via the implementation of Decentralization Laws in 1999 had fundamentally altered the power dynamics and relations between national and local government units. This process gave provincial and regency/city governments authority to pass and implement perda or regional regulations except in those areas that remain exclusively under the ambit of the central government including foreign affairs, national defense, national security, justice, economic policy, and religion. ${ }^{10}$ However, due to the lack of strong check and balance mechanisms and problems relating to legislative ambiguity, local officials have been able to design and execute certain religious regulations without being questioned or opposed by the central authorities. These instruments have been introduced in various forms which are neither stipulated under the Decentralized Laws nor officially recognized in the Indonesian legal system such as letters written by the governor, instructions coming from the mayor, and circulars and appeals released by the regent (Crouch 2009). Attempts by the national government in Jakarta to control the forms of laws being adopted at local levels have been insufficient for monitoring the law-making

${ }^{10}$ Author's interview with a key informant in Yogyakarta, Indonesia on August 18, 2017. See also, Tyson 2011; Heffner 2011. 
activities of provincial elites especially with regard to religious matters.

Some of these regulations have been espoused to facilitate the full implementation of Shari'a. The most notable example is the Qanun that has been adopted in Aceh which is currently the only province that has the authority to develop Islamic structures of governance under special autonomy. This gave the people of Aceh the powers to: (1) establish Shari'a administrative institutions including a court, a religious police, and a department of government; and (2) enforce vital aspects of the Shari'a law governing the Islamic creed, worship, finance, and morality (Feener 2013). Other regulations have been focused on embedding Islamic values when designing a particular region's local governance systems or setting its future goals. The Strategic Plan for West Java (2001-2005), for example, identified religion as one of the province's core principles, linking Islam to concepts of equality and progress (Crouch 2009). And then there are those regulations that have strengthened orthodox systems and arrangements of local governance by denoting Shari'a either as a part of or in addition to Muslim customary practices and traditions or the adat. For instance, West Sumatra's numerous nagari (village) regulations are anchored on the customary philosophy that recognizes the Quran as the ultimate basis of Islamic laws and the root of their Minangkabau mores and customs (Biezeveld 2007; Davidson and David 2007).

Indeed, the overhauling of Indonesian government system through decentralization process generated vital instruments for expressing and delineating competing ethnoreligious identities, specifically between the Muslims and the Christians. The breakdown of the New Order produced anxieties among the members of these two factions who were facing uncertainties over their role and position in the emerging new Indonesia. ${ }^{11}$ The construction of these wide-ranging religious regulations underscores the Muslim's fears precipitated by 'Christian pressures' on the basic premises of the Indonesian identity and homeland, on the one hand; and their desires to renegotiate and reconfigure of this identity and homeland by curtailing the Christians' political power, representation, access, and authority. This had been clearly evident in the manner in which powerful Muslim politicians and elites behaved throughout the duration of the conflict in Maluku.

"Author's interview with a key informant in Jakarta, Indonesia on August 15, 2017. 
For Islamists and conservative Muslims, the Christian petition for United Nations intervention and the formation of the Maluku Sovereignty Front to revive the Republic of South Maluku movement, were solid proofs of the conspiracy to dismember and destroy the largest Muslim country in the world (Goss 2000; Wilson 2008; van Klinken 2007). Accordingly, militant Islamist groups, particularly the Laskar Jihad, justified their waging of jihad in Ambon as a 'humanitarian mission' to save Maluku and its people from Christianity's deceptions and distorted doctrines by converting them back to Islam. ${ }^{12}$ The goal was to reform the entire Indonesia into a Shari'a-ruled Islamic state. Ambon served as the starting point for pursuing this cause by testing the strength and resolve of non-Muslim resistance, as well as the response and sentiments of the Indonesian state and the Muslim populations. ${ }^{13}$ Widespread perceptions that ethnoreligious concerns and interests were the reasons behind the Islamist militants' violent intervention against the Indonesian Christians prevented both local and national government units from adopting decisive measures to end the attacks.

Indeed, the events that unfolded in Maluku underscored the grave consequences of Suharto's decision to repress and ignore ethnoreligious tensions for more than three decades on the capacity and effectiveness of the government in addressing the causes of the problems. The confusion and chaos brought about by the start of reformasi transition forced state actors to prioritize the security and stability of post-Suharto Indonesia at the national level, rather than focusing on the local clashes taking place in various parts of Maluku. Underestimating the magnitude and extent of the conflict, the politicians in Jakarta depended on military personnel to control the situation who, in turn, relied on local civilians for guidance (Schulze 2002). But as in the case of Ambon, for example, the Muslim governor and the Christian commander of the Maluku military district had both been reluctant to intervene due to fears that their actions would be interpreted as partiality toward their respective communities (Hasan 2002). Even Indonesia's then president, Abdurrahman Wahid refused to act and distanced himself from the situation, claiming that the people of Maluku must be allowed to resolve their problems on their own (Goss 2000). The state had virtually passed on the tremendous responsibility of settling the conflict in

\footnotetext{
${ }_{12}$ Author's interview with a key informant in Yogyakarta, Indonesia on August 19, 2017.
}

${ }^{13}$ Author's interview with a key informant in Yogyakarta, Indonesia on August 19, 2017. 
the hands of the warring enclaves, thereby letting itself to be usurped and used by paramilitary groups. This general paralysis, if not apathy, among government officials greatly contributed to the contamination of members of the local army and the police who had been successfully recruited by Muslim and Christian fighters attempting to reinforce their ranks and cement their positions. ${ }^{14}$

To a large extent, this seemingly nonchalant attitude of the national government toward the violent incidents plaguing Maluku was driven by the underlying fear and opportunism on the part of key state agents. Several high-ranking politicians in Jakarta saw the situation as an opportunity to further enhance their own popular appeal and secure their position by exploiting Islam's political currency (Davis 2002; Hassan 2002). The rekindling of Islamic national identity among the Indonesian Muslims made it extremely difficult for officials to publicly condemn let alone stop the mujahideen's activities in Maluku. ${ }^{15}$ Those who tried to facilitate peace talks on the grounds of equality and mutual tolerance between Muslims and Christians were accused of being infidels and Christian sympathizers. ${ }^{16}$ The political costs of being labelled an anti-Muslim and, conversely, the rewards for backing up or at least condoning the Islamists, forestalled any meaningful conflict resolution plan. Mainstream Muslim organizations also helped legitimize the presence of Islamic militants in Maluku by not challenging the latter's extremist ideologies, thereby reinforcing the sense that Indonesian Islamic faith and laws were less genuine than the Salafi movement and Shari'a system being imposed by these actors (Davis 2002; Schulze 2002). All this silence and inaction led to the perception among ordinary Indonesian Muslims that without the Islamist groups in Maluku, particularly the Laskar Jihad, the entire region would have been vulnerable to Christian counterattacks.

Accordingly, rather than providing equal rights and protection for the Christians in Maluku, the democratization process and the institutions it created provided channels for the (re)Islamization of Indonesia at the expense of all other non-Muslims. The electoral cost and utility of Islam-centric religious regulations makes it highly problematic for national and local politicians and other elites to review, let alone revoke them. At the core of this Muslim-Christian

${ }^{14}$ Author's interview with a key informant in Jakarta, Indonesia on August 15, 2017.

${ }^{15}$ Author's interview with a key informant in Yogyakarta, Indonesia on August 20, 2017.

${ }^{16}$ Author's interview with a key informant in Jakarta, Indonesia on August 15, 2017. 
dilemma are fundamental albeit unsettled disputes over the principles and sources of national identity and homeland in terms of the legitimate versus illegitimate members; the rightful versus illegal owners; the authentic versus fraud ethnie and faith. In times of crisis, breakdown, and threat, these ethnoreligious allegiances magnify the strangeness of the others, transforming imagined insecurities and differences into concrete existential threats and social hierarchies. As violent conflicts begin to assume and crystallize around ethnoreligious identities secular scenarios turn sectarian, thwarting whatever semblance of hitherto harmony and co-existence that might have bound Muslim and Christian constituencies together (Bubandt 2001; Liow 2016).

\section{Conclusions}

How does a once familiar and benign ethnoreligious community become a stranger and a threat? I have devised and tested a framework that captures the three-phase cycle that drives and underpins the manufacturing of ethnoreligious others into security threats. First, it is important to acknowledge the existence of emotions. Although these emotions, along with the motives and intentions that they engender are often ambiguous and difficult to systematically assess, they are central to understanding the first stage in the transformation of imagined insecurities into concrete existential threats. By cultivating ethnoreligious nationalism, certain belief systems expressed in chauvinistic conceptions and narratives about the self and the others emerge. These then generate a combination of usually hostile emotive effects which in turn, influence individual/group motives and intentions. In the case of Indonesia, the historical structural changes that took place (from Dutch colonization to rise and fall of Suharto's New Order and all the way to reformasi period and the present era) have resulted in fears that intensified the Muslim and Christian groups' need for greater security; triggered ancient hatreds that made Muslim and Christian groups deeply suspicious of each other's real motives and intentions; and fueled resentments that compelled Muslim and Christian groups to challenge and undermine each other's legitimacy and status. Together, these hostile emotive effects function as a 'switch' that 'heightens the saliency of a particular concern' (Petersen 2002, 37) which in this case are the 'illegitimate', 'different', 'impure' ethnoreligious others. 
Second, the hostile emotive effects which have been cultivated from ethnoreligious nationalism motivate ethnoreligious groups, specifically their elites, to securitize rival factions as threats to their own security and power position using equally hostile symbolic predispositions. These predispositions are anchored on the underlying ethnoreligious substructures (the respective doctrines, myths, dogmas, and norms of competing groups) used to identify the others as enemies and construct stereotypes about these enemies which define certain biases and prejudices. The elites' efforts in framing the perceived Islamisasi and Kristenisasi of the whole Indonesian archipelago as a threat toward Christian and Muslim communities respectively, were intended to resonate strongly and clearly with the predispositions of their target audiences. Doing so enabled the elites from whichever was the more politically influential ethnoreligious group at the time to develop, implement, and rationalize security superstructures (rhetoric, policies, strategies, and institutions) designed to enhance their relative position and power within the territorially bounded polity of Indonesia. The 'mass hostility, chauvinist political mobilization, and a security dilemma' (Kaufman 2006, 53) which resulted from the securitization of ethnoreligious others justified the extraordinary measure that was deemed necessary to protect the identities and territories at stake: the resort to violent Muslim-Christian conflicts that claimed thousands of lives.

Finally, the perceived indivisibility of ethnoreligious identities and territories motivate rival groups to further bolster their claims about the sacredness of their own collective identity and homeland which cannot be simply shared with others. Such mentality pushes the elites from rival groups to gain significant leverage over the nature and composition of state security superstructures by attempting to ensconce their own ethnoreligious substructures into these instruments. Success in doing so would enhance and sustain a group's structural power position relative to the other factions. The goal is to avoid being relegated to the periphery as that would considerably curtail the ability of the group to shape the security rhetoric, policies, strategies, and institutions needed to provide greater space and privileges for its members. Regardless of the exact nature of their function vis-à-vis the elites - either essentialist (substantively linked) or instrumentalist (tactically linked) - these nonrational, nonmaterial elements are vessels through which the distribution of institutional security and structural power between the 'self' and the 
'others' are revised and recalibrated. The constantly shifting tides of authority and influence between the Muslim and Christian elites along the corridors of power in Jakarta - from the country's independence up to the present age of reformation - revealed the precarity of losing substantial access and control over these security superstructures. The modernist and secularist effects of globalization have not exactly desacralized the concepts of identity and the homeland. The crystallization of imagined insecurities into bloodbaths that engulfed and destroyed the imagined communities of Muslim and Christians in Indonesia proved that they remain indivisible and sacred in the $21^{\text {st }}$ century.

\section{References}

Abuza, Zachary. 2006. Political Islam and Violence in Indonesia. London: Routledge.

Acemoglu, Daron, and James Robinson. 2012. Why Nations Fail: The Origins of Power, Prosperity, and Poverty. New York: Crown Books.

Alexander, Michele, Marilynn Brewer, and Richard Hermann. 1999. "Images and Affect: A Functional Analysis of Out-group Stereotypes." Journal of Personality and Social Psychology 77(1): 78-93.

Arifianto, Alexander. 2009. "Explaining the Cause of Muslim-Christian Conflicts in Indonesia: Tracing the Origins of Kristenisasi and Islamisasi." Islam and Christian-Muslim Relations 20(1): 73-89.

Aritonang, Jan Sihar, and Karel Steenbrink, eds. (2008). A History of Christianity in Indonesia. Leiden: Brill.

Armstrong, John. 1997. "Religious Nationalism and Collective Violence." Nations and Nationalism 3(4): 597-606.

Ashmore, Richard, Lee Jussim, and David Wilder, eds. 2011. Social Identity, Intergroup Conflict, and Conflict Reduction. Oxford: Oxford University Press.

Aspinall, Edward, and Mark Berger. 2001. "The Break-up of Indonesia? Nationalisms after Decolonisation and the Limits of the Nation-State in Post-Cold War Southeast Asia." Third World Quarterly 22(6): 1003-1024.

Bagge Laustsen, Carsten, and Ole Wæver. 2000. "In Defence of Religion: Sacred Referent Objects for Securitization." Millennium 29(3): 705-739.

Balzacq, Thierry, ed. 2010. Understanding Securitisation Theory: How Security Problems Emerge and Dissolve. London: Routledge. 
Baswedan, Anies Rasyid. 2004. "Political Islam in Indonesia: Present and Future Trajectory." Asian Survey 44 (5): 669-690.

Boland, Bernard Johan. 1982. The Struggle of Islam in Modern Indonesia. Leiden: Springer Science \& Business Media.

Bosco, Robert. 2014. Securing the Sacred: Religion, National Security, and the Western State. Michigan: University of Michigan Press.

Bowen, John. 2003. Islam, Law, and Equality in Indonesia: An Anthropology of Public Reasoning. New York: Cambridge University Press.

Brubaker, Rogers. 2012. "Religion and Nationalism: Four Approaches." Nations and Nationalism 18(1): 2-20.

Bubandt, Nils. 2001. "Malukan Apocalypse: Themes in the Dynamics of Violence in Eastern Indonesia." In Violence in Indonesia, eds. Ingrid Wessel and Georgia Wimhö fer. Hamburg: Abera-Verlag, 243-246.

Bull, Hedley. 2012. The Anarchical Society: A Study of Order in World Politics. New York: Macmillan International Higher Education.

Buzan, Barry, Ole Wæver, and Jaap De Wilde. 1998. Security: A New Framework for Analysis. New York: Lynne Rienner Publishers.

Crouch, Melissa. 2011. "Law and Religion in Indonesia: The Constitutional Court and the Blasphemy Law." Asian Journal of Comparative Law 7(1): 1-46.

Crouch, Melissa. 2007. "Regulating Places of Worship in Indonesia: Upholding Freedom of Religion for Religious Minorities." Singapore Journal of Legal Studies 1(1): 96-116.

Crouch, Melissa. 2009. "Religious Regulations in Indonesia: Failing Vulnerable Groups?." Review of Indonesian and Malaysian Affairs 43(2): 1-51.

David Stevens, 1997. "Nationalism as Religion." Studies: An Irish Quarterly Review 86 (343): 248258.

Davidson, Jamie, and David Henley, eds. 2007. The Revival of Tradition in Indonesian Politics: The Deployment of Adat from Clonialism to Indigenism. New York: Routledge.

Davis, Michael. 2002. "Laskar Jihad and the Political Position of Conservative Islam in Indonesia." Contemporary Southeast Asia 24(1): 12-32.

Douglas Johnston and Cynthia Sampson, eds. 1995. Religion: The Missing Dimension of Statecraft. New York: Oxford University Press.

Edwards, Kari, and William Von Hippel. 1995. "Hearts and Minds: The Priority of Affective versus Cognitive Factors in Person Perception." Personality and Social Psychology Bulletin 21(10): 996-1011.

Edwards, Kari. 1990. "The Interplay of Affect and Cognition in Attitude Formation and Change." Journal of Personality and Social Psychology 59(2 ): 202-216. 
Jean Elshtain, ed. 1992. Just War Theory. New York: New York University Press.

Elson, Robert. 2009. "Another Look at the Jakarta Charter Controversy of 1945." Indonesia 88(0): 105-130.

Federspiel, Howard. 2009. Persatuan Islam: Islamic Reform in Twentieth Century Indonesia. Jakarta: Equinox Publishing.

Feener, Michael. 2013. Shari'a and Social Engineering: The Implementation of Islamic Law in Contemporary Aceh, Indonesia. Oxford: Oxford University Press.

Feillard, Andrée, and Rémy Madinier. 2011. The End of Innocence?: Indonesian Islam and the Temptations of Radicalism. Hawaii: University of Hawaii Press.

Floyd, Rita. 2011. "Can Securitization Theory be Used in Normative Analysis? Towards a Just Securitization Theory." Security Dialogue 42(4-5): 427-439.

Fox, Jonathan, and Shmuel Sandler, eds. 2004. Bringing Religion into International Relations. New York: Springer.

Friedland, Roger. 2001. "Religious Nationalism and the Problem of Collective Representation." Annual Review of Sociology, 27(1): 125-152.

Geneviève Zubrzycki, ed. 2017. National Matters: Materiality, Culture, and Nationalism. California: Stanford University Press.

Gerd Baumann. 1999. The Multicultural Riddle: Rethinking National, Ethnic and Religious Identities. New York: Routledge.

Goss, Jon. 2000. "Understanding the Maluku Wars: Overview of Sources of Communal Conflict and Prospects for Peace." Cakalele 11(0): 7-39.

Hamayotsu, Kikue. 20002. "Islam and Nation Building in Southeast Asia: Malaysia and Indonesia in Comparative Perspective." Pacific Affairs 75(3): 1-19.

Hasan, Noorhaidi. 2002. "Faith and Politics: The rise of the Laskar Jihad in the Era of Transition in Indonesia." Indonesia 73 (0): 145-169.

Hassner, Ron. 2003. "To Halve and to Hold": Conflicts over Sacred Space and the Problem of Indivisibility. Security Studies 12(4): 1-33.

Hassner, Ron. 2007. "Islamic Just War Theory and the Challenge of Sacred Space in Iraq." Journal of International Affairs 61(1): 131-152.

Hastings, Adrian. 1977. The Construction of Nationhood: Ethnicity, Religion and Nationalism. New York: Cambridge University Press.

Hefner, Robert. 2011. Civil Islam: Muslims and Democratization in Indonesia. New Jersey: Princeton University Press.

Herrmann, Richard. 2017. "How Attachments to the Nation Shape Beliefs About the World: A Theory of Motivated Reasoning." International Organization, 71(1): 61-84. 
Hoey, Brian. 2003. "Nationalism in Indonesia: Building Imagined and Intentional Communities Through Transmigration." Ethnology 42(2): 109-126.

Hosen, Nadirsyah. 2005. "Religion and the Indonesian Constitution: A Recent Debate." Journal of Southeast Asian Studies 36(3): 403-424.

Hughey, Michael, ed. 1998. New Tribalisms: The Resurgence of Race and Ethnicity. London: Macmillan Press.

Husein, Fatimah. 2004. Muslim-Christian Relations in the New Order Indonesia: The Exclusivist and Inclusivist Muslims' Perspectives. Jakarta: PT Mizan Publika.

Ignatieff, Michael. 1993. Blood and Belonging: Journeys into the New Nationalism. London: Vintage.

Juergensmeyer, Mark. 1993. Religious Nationalism Confronts the Secular State. New York: Oxford University Press.

Juergensmeyer, Mark. 1996. "The Worldwide Rise of Religious Nationalism." Journal of International Affairs 50(1): 1-20.

Karyotis, Georgios, and Stratos Patrikios. 2010. "Religion, Securitization and Anti-immigration Attitudes: The Case of Greece." Journal of Peace Research 47(1): 43-57.

Kaufman, Stuart. 2001. Modern Hatreds: The Symbolic Politics of Ethnic War. New York: Cornell University Press.

Kaufman, Stuart. 2006. "Symbolic Politics or Rational Choice? Testing Theories of Extreme Ethnic Violence." International Security 30(4): 45-86.

Kinnvall, Catarina. 2004. "Globalization and Religious Nationalism: Self, Identity, and the Search for Ontological Security." Political Psychology 25(5): 741-767.

Laffan, Michael Francis. 2003. Islamic Nationhood and Colonial Indonesia: The Umma below the Winds. London: Routledge.

Liddle, William. 1996. "The Islamic Turn in Indonesia: A Political Explanation." The Journal of Asian Studies 55(3): 613-634.

Liow, Joseph. 2016. Religion and Nationalism in Southeast Asia. New York: Cambridge University Press.

Morfit, Michael. "Pancasila: The Indonesian state Ideology according to the New Order Government." Asian Survey 21, no. 8 (1981): 838-851

Morley, David, and Kevin Robins. 1994. "No Place Like Heimat: Images of Homeland in European Culture." In Spaces of Identity: Global Media, Electronic Landscapes and Cultural Boundaries, eds. David Morley and Kevin Robins. London: Routledge, 85-104.

Mortimer, Rex. 2006. Indonesian Communism Under Sukarno: Ideology and Politics, 1959-1965. Sheffield: Equinox Publishing.

Mujani, Saiful, and R. William Liddle. 2009. "Muslim Indonesia's Secular Democracy." Asian Survey 49(4): 575-590. 
Nenchik, Jeremy. 2016. Islam and Democracy in Indonesia: Tolerance without Liberalism. New York: Cambridge University Press.

Ole Wæver. 1995. “Securitization and Desecuritization.” In On Security, ed. Ronnie Lipschutz. New York: Columbia University Press, 46-86.

Ortony, Andrew, Gerald Clore, and Allan Collins. 1988. The Cognitive Structure of Emotions. New York: Cambridge University Press.

Petersen, Roger. 2002. Understanding Ethnic Violence: Fear, Hatred, and Resentment in TwentiethCentury Eastern Europe. New York: Cambridge University Press.

Hatzopoulos, Pavlos, and Fabio Petito, eds. 2003. Religion in International Relations: The Return from Exile. New York: Palgrave Macmillan.

Riek, Blake, Eric Mania, and Samuel Gaertner. 2006. "Intergroup Threat and Outgroup Attitudes: A Meta-analytic Review." Personality and Social Psychology Review 10(4): 336-353.

Robins, Robert, and Jerrold Post. 1997. Political Paranoia: The Psychopolitics of Hatred. Connecticut: Yale University Press.

Roff, William. 1967. The Origins of Malay Nationalism. Connecticut: Yale University Press.

Ross, Marc. 2001. "Psychocultural Interpretations and Dramas: Identity Dynamics in Ethnic Conflict." Political Psychology 22(1): 157-178.

Schulze, Kirsten. 2002. "Laskar Jihad and the Conflict in Ambon." The Brown Journal of World Affairs 9(1): 57-69.

Sidel, John. 2006. Riots, Pogroms, Jihad: Religious Violence in Indonesia. New York: Cornell University Press.

Smith, Anthony. 2000. "The Sacred Dimension of Nationalism." Millennium 29(3): 791-814.

Smith, Anthony. 2003. Chosen Peoples: Sacred Sources of National Identity. New York: Oxford University Press.

Spohn, Willfried. 2003. "Multiple Modernity, Nationalism and Religion: A Global Perspective." Current Sociology 51(3-4): 265-286.

Spyer, Patricia. 2002. "Fire Without Smoke and Other Phantoms of Ambon's Violence: Media Effects, Agency, and the Work of Imagination." Indonesia 74(0): 21-36.

Stavenhagen, Rodolfo. 1996. Ethnic Conflicts and the Nation-State. London: Macmillan Press.

Stritzel, Holger. 2007. "Towards a Theory of Securitization: Copenhagen and Beyond." European Journal of International Relations 13(3): 357-383.

Thomas, Scott. 2005. The Global Resurgence of Religion and the Transformation of Onternational Relations: The Struggle for the Soul of the Twenty-first Century. London: Springer. 
Toft, Monica. 2005. The Geography of Ethnic Violence: Identity, Interests, and the Indivisibility of Territory. Princeton University Press.

Turner, Kathleen. 2003. "Myths and Moral Authority in Maluku: The case of Ambon." Asian Ethnicity 4(2): 241-263.

Tyson, Adam. 2010. Decentralization and Adat Revivalism in Indonesia: The Politics of Becoming Indigenous. London: Routledge.

Volkan, Vamik. 1998. Bloodlines: From Ethnic Pride to Ethnic Terrorism. New York: Basic Books. van Bruinessen, Martin. 2002. "Genealogies of Islamic Radicalism in Post-Suharto Indonesia." South East Asia Research 10(2): 117-154.

van Klinken, Gerry. 2007. Communal Violence and Democratization in Indonesia: Small Town Wars. London: Routledge.

van Klinken, Gerry. 2003. Minorities, Modernity and the Emerging Nation: Christians in Indonesia, A biographical Approach. Leiden: Brill.

van Liere, Lucien. 2011. "Fighting for Jesus on Ambon: Interpreting religious representations of violent conflict." Exchange 40(4): 322-335.

Wentz, Richard. 1987. Why People Do Bad Things in the Name of Religion. Georgia: Mercer University Press.

Westen, Drew. 2007. The Political Brain: The Role of Emotion in Deciding the Fate of the Nation. New York: Public Affairs.

Wilson, Chris. 2005. "The Ethnic Origins of Religious Conflict in North Maluku Province, Indonesia, 1999-2000." Indonesia 79(0): 69-91.

Wilson, Chris. 2008. Ethno-religious Violence in Indonesia: From Soil to God. New York: Routledge. 